NOTE

\title{
Carbohydrate composition of mucus released by scleractinian warm- and cold-water reef corals
}

\author{
Christian Wild*, Malik Naumann, Wolfgang Niggl, Andreas Haas \\ Coral Reef Ecology Group (CORE), GeoBio-Center \& Department of Earth and Environmental Science, \\ Ludwig-Maximilians-Universität, Richard Wagner Str. 10, 80333 München, Germany
}

\begin{abstract}
Mucus, a complex composed primarily of carbohydrates, is released in similar quantities by scleractinian warm- and cold-water reef corals, and can function as an important carrier of organic material from corals to a range of consumers, microbes in particular. However, information about mucus chemical composition is rare for warm-water corals and non-existent for cold-water corals. This study therefore presents comparative carbohydrate composition analyses of mucus released by the dominant and cosmopolitan warm- and cold-water coral genera. Arabinose was the major mucus carbohydrate component for the genus Acropora, but was not found in cold-water coral mucus. Mucus derived from corals of the genus Fungia contained significantly more fucose than the mucus of all other coral genera. However, comparison of mucus carbohydrate composition for the warm- and cold-water corals in the present study and in the literature revealed no significant differences. This indicates use of similar carbohydrate components (with the exception of arabinose) during mucus synthesis by scleractinian corals, largely irrespective of zooxanthellate or azooxanthellate carbon supply mechanisms.
\end{abstract}

KEY WORDS: Warm-water coral · Cold-water coral $\cdot$ Mucus $\cdot$ Chemical composition $\cdot$ Carbohydrate Microbes $\cdot$ Degradability

\section{INTRODUCTION}

Both scleractinian warm- and cold-water corals (termed WC and CC hereafter) continuously release mucus into their surroundings in similar quantities (Wild et al. 2005a, 2008) for various purposes (reviewed in Brown \& Bythell 2005). This mucus is released in such quantities that it can dominate the suspended matter around WC reefs (Johannes 1967, Marshall 1968) and may also control the carbon cycle in the water column above $\mathrm{CC}$ reefs by stimulating microbial growth that contributes to fast conversion of coralderived dissolved organic carbon (DOC) into particulate organic carbon (POC) (Wild et al. 2008, 2009).

Previous studies confirmed the important function of WC derived mucus as an energy carrier and particle trap in the reef ecosystem (Wild et al. 2004a, Huettel et al. 2006, Naumann et al. 2009). Coral mucus is rapidly degraded by microbes in the pelagic and benthic environment at reef locations in the Australian Great Barrier Reef (Wild et al. 2004b) and the Northern Red Sea (Wild et al. 2005b). For CC derived mucus, faunamicrobe interactions via this material and its fast recycling by planktonic microbes have been observed (Wild et al. 2008). Supplementary research revealed similar planktonic microbial degradation of mucus released by CC coral Lophelia pertusa, compared to degradation of the carbohydrates starch and glucose (Wild et al. 2009).

However, information about the chemical composition of WC derived mucus is very limited and is nonexistent for $\mathrm{CC}$ derived mucus. WC derived mucus has been described as a primarily carbohydrate complex (Coffroth 1990), but more detailed chemical analyses 
revealed that the main component of mucus released by the staghorn coral Acropora formosa consisted of a proteoglycan (Richards et al. 1983). Wild et al. (2005a) further analysed the carbohydrate composition of mucus released by 6 different coral species within the genus Acropora and found arabinose, mannose, galactose, glucose and $\mathrm{N}$-acetyl glucosamine present in all samples, whereas rhamnose, fucose and xylose were detected only in some samples. Such differences in mucus composition may control microbial community composition in WC (Allers et al. 2008) and CC reef habitats (Schöttner et al. 2009), with ensuing effects on microbial activity.

In comparison with zooxanthellate $\mathrm{WC}$, azooxanthellate CC likely release mucus with a distinctly different carbohydrate composition, as they do not receive any photosynthetically produced transfer metabolites. Up to half of the carbon assimilated by the endosymbiotic algae can be released as mucus by WC (Crossland et al. 1980, Davies 1984), and chemical analyses showed that carbohydrate mucus components such as arabinose may be directly transferred from the algae to the coral host (Meikle et al. 1988).

Substrate specificity in marine polysaccharide complexes is, however, critical for microbial degradation and concomitant organic matter recycling (Arnosti 2000). The present study therefore presents carbohydrate compositions of mucus released from dominant WC genera (Acropora, Stylophora, Pocillopora, Fungia and Ctenactis) in comparison to the 2 cosmopolitan CC genera Lophelia and Madrepora. In addition, all literature data available for carbohydrate composition of warm-water coral-derived mucus are compared to cold-water coral mucus carbohydrate composition data, which are presented here for the first time.

\section{MATERIALS AND METHODS}

Collection of mucus samples. Warm-water scleractinian corals were collected by SCUBA from water depths of ca. $5 \mathrm{~m}$ within a fringing reef close to the Marine Science Station in Aqaba, Jordan $\left(29^{\circ} 27^{\prime} \mathrm{N}\right.$, $34^{\circ} 58^{\prime} \mathrm{E}$ ), during 3 seasonal expeditions (Aug-Sep 2007, Feb-Mar 2008 and May 2008). For each mucus sampling, 4 to 6 different Acropora, Stylophora or Pocillopora colonies (diameter: 21 to $45 \mathrm{~cm}$ ) or polyps of Fungia or Ctenactis (diameter: 21 to $43 \mathrm{~cm}$ ) were used. All coral colonies or polyps were kept in flow-through aquaria at in situ temperature and light availability for 24 to $48 \mathrm{~h}$ prior to mucus sampling in order to avoid mucus contamination because of lesion leakage. Mucus was then collected from each coral genus by using the methodology described in Wild et al. (2005a). Briefly, corals were turned upside-down and exposed to air for $2 \mathrm{~min}$. They immediately began to release fluid, transparent mucus in variable volumes. The dripping mucus was collected in a clean container after discarding the initial $30 \mathrm{~s}$ of dripping. Mucus collected from colonies or polyps of the same genus was pooled and frozen at $-20^{\circ} \mathrm{C}$ in volumes of 8 to $12 \mathrm{ml}$ until further analysis.

Cold-water corals were collected either by the manned submersible JAGO (IFM-Geomar, Kiel, Germany) during 3 dives at Røst Reef $\left(67^{\circ} 31.11^{\prime} \mathrm{N}\right.$, $9^{\circ} 28.43^{\prime} E_{\text {; }}$ water depths: 310 to $380 \mathrm{~m}$ ), Norway, during the RV 'Polarstern' expedition ARK-XXII/1a, or by a remotely operated vehicle (ROV) of type Sperre SUBfighter $7500 \mathrm{DC}$ from dives at Tisler Reef $\left(58^{\circ} 59.81^{\prime} \mathrm{N}\right.$,

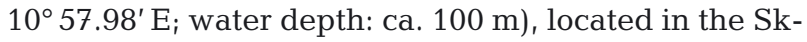
agerrak at the border between Sweden and Norway. From both Røst and Tisler Reefs, 4 to 8 fragments (length: 10 to $25 \mathrm{~cm}$ ) from different colonies of the genera Lophelia (both reefs) and Madrepora (only Røst Reef) were collected and kept in seawater at in situ temperature for at least $5 \mathrm{~d}$ prior to mucus sampling in order to avoid mucus contamination because of lesion leakage. This maintenance water was collected from either the water depth of coral sampling (Røst Reef) or pumped from the field (water depth: ca. $50 \mathrm{~m}$ ) and prefiltered over coarse sand (Tisler Reef). Water was exchanged at a rate of $50 \%$ at least every second day. Corals were not externally fed during maintenance in the aquaria, but could feed on dissolved and particulate natural organic matter suspended in the incubation water. Maintenance conditions of corals were therefore very close to in situ conditions. Mucus was then collected from both cold-water coral genera during the 2 expeditions as described above in volumes of 2 to $10 \mathrm{ml}$. Coral mucus samples were kept frozen at $-20^{\circ} \mathrm{C}$ until further analysis.

Carbohydrate composition. Coral mucus samples were desalted prior to carbohydrate composition analysis using a Spectra/Por Biotech cellulose ester dialysis membrane with a molecular weight cutoff of 100 to $500 \mathrm{Da}$. A length of membrane sufficient to hold $2 \mathrm{ml}$ of liquid was cut off from the $10 \mathrm{~m}$ strip and washed using deionized, sterile water. The membrane was then filled with approximately $2 \mathrm{ml}$ of sample and placed in a $4 \mathrm{l}$ bucket that was continuously filled with new deionized, sterile water from the bottom and emptied from the top. A stir bar was employed to aid mixing at $4^{\circ} \mathrm{C}$. After $3 \mathrm{~d}$, the samples were removed, frozen and lyophilized. Glycosyl composition analysis was performed by combined gas chromatography-mass spectrometry (GC-MS) of the per-O-trimethylsilyl (TMS) derivatives of the monosaccharide methyl glycosides produced from the sample by acidic methanolysis. An aliquot was taken from each sample and added to separate tubes with $40 \mu \mathrm{g}$ of inositol as the internal stan- 
dard. Methyl glycosides were then prepared from the dry sample following a mild acid treatment by methanolysis in $1 \mathrm{M} \mathrm{HCl}$ in methanol at $80^{\circ} \mathrm{C}$ for $16 \mathrm{~h}$, followed by re- $N$-acetylation with pyridine and acetic anhydride in methanol (for detection of amino sugars). The sample was then per-O-trimethylsilylated by treatment with Tri-Sil (Pierce) at $80^{\circ} \mathrm{C}$ for $0.5 \mathrm{~h}$, as described in York et al. (1986) and Merkle \& Poppe (1994). GC-MS analysis of the TMS methyl glycosides was performed on an AT $6890 \mathrm{~N}$ GC interfaced to a 5975B mass selective detector (Agilent Technologies), using a Supelco EC-1 fused silica capillary column (30 $\mathrm{m} \times 0.25 \mathrm{~mm}$ ID).

Statistical analysis. $U$-rank sum tests after Wilcoxon, Mann and Whitney were carried out for all statistical evaluations as this test does not require homogeneity of variances or a normal distribution.

\section{RESULTS AND DISCUSSION}

C6 sugars (glucose, mannose and galactose) occurred most often, followed by deoxysugars (fucose and rhamnose), amino sugars (N-acetyl glucosamine) and C5 sugars (arabinose and xylose) (Table 1). The monosaccharide arabinose, often detected as a compound of biopolymers such as hemicellulose and pectin, was only found in mucus released by warmwater corals of the genus Acropora, where it was the major carbohydrate component. Analysis of all available similar data sets on the carbohydrate composition of WC mucus from the literature (Richards et al. 1983, Meikle et al. 1988, Wild et al. 2005a) confirmed that Acropora mucus ( $\mathrm{n}=8$ samples from different species including A. aspera, A. digitera, A. formosa, A. millepora, A. nobilis and A. pulchra) contained significantly

Table 1. Carbohydrate composition (in mole percentage of all detected carbohydrates) of mucus released from different scleractinian warm- and cold-water coral genera investigated in the present study in comparison with all available data from the literature. Ara: arabinose; Rha: rhamnose; Fuc: fucose: Xyl: xylose; Man: mannose; Gal: galactose; Glc: glucose; GlcNAc: N-acetyl glucosamine; nd: not detected; n/a: not analyzed. Glucuronic acid, galacturonic acid, N-acetyl galactosamine and N-acetyl mannosamine could not be detected in any of the samples

\begin{tabular}{|c|c|c|c|c|c|c|c|c|c|}
\hline Origin (season) & Ara & Rha & Fuc & Xyl & Man & Gal & Glc & GlcNAc & Source \\
\hline \multicolumn{10}{|l|}{ Acropora } \\
\hline Aqaba, Jordan (summer) & 76.4 & nd & 6.5 & nd & 5.7 & 3.7 & 1.2 & 6.6 & \multirow{7}{*}{$\begin{array}{l}\text { Present study } \\
\text { Wild et al. (2005a) }\end{array}$} \\
\hline \multirow[t]{6}{*}{ Heron Island, Australia } & 50.8 & nd & 5.5 & nd & 10.6 & 6.2 & 13.2 & 13.7 & \\
\hline & 13.9 & 2.8 & 5.0 & 4.0 & 12.0 & 5.3 & 40.5 & 16.4 & \\
\hline & 36.7 & nd & 5.6 & nd & 12.8 & 5.4 & 22.2 & 17.2 & \\
\hline & 63.2 & nd & nd & nd & 11.1 & 5.3 & 12.5 & 7.9 & \\
\hline & 24.6 & 8.0 & 6.6 & 4.7 & 13.4 & 5.9 & 22.1 & 10.6 & \\
\hline & 25.4 & nd & 7.8 & 9.8 & 11.1 & 2.9 & 32.2 & 10.7 & \\
\hline Magnetic Island, Australia & 47.0 & $\mathrm{n} / \mathrm{a}$ & 2.0 & nd & 18 & 2.0 & 1.0 & 29.0 & Meikle et al. (1988) \\
\hline \multicolumn{10}{|l|}{ Ctenactis } \\
\hline Aqaba, Jordan (winter) & nd & nd & 5.2 & nd & 22.1 & 6.0 & 5.9 & 60.8 & Present study \\
\hline \multicolumn{10}{|l|}{ Fungia } \\
\hline Aqaba, Jordan (spring) & nd & nd & 68.4 & nd & 31.6 & nd & nd & nd & \multirow[t]{3}{*}{ Present study } \\
\hline Aqaba, Jordan (summer) & nd & nd & 78.7 & nd & 15.0 & 0.7 & 0.9 & 4.7 & \\
\hline Aqaba, Jordan (winter) & nd & nd & 85.8 & nd & 14.2 & nd & nd & nd & \\
\hline Magnetic Island, Australia & 2.0 & $\mathrm{n} / \mathrm{a}$ & 41.0 & 2.0 & 19.0 & 4.0 & 3.0 & 22.0 & Meikle et al. (1988) \\
\hline \multicolumn{10}{|l|}{ Pocillopora } \\
\hline Aqaba, Jordan (winter) & nd & nd & 25.3 & nd & 49.5 & nd & 25.2 & nd & Present study \\
\hline \multicolumn{10}{|l|}{ Stylophora } \\
\hline Aqaba, Jordan (winter) & nd & nd & nd & nd & nd & nd & 100.0 & nd & Present study \\
\hline \multicolumn{10}{|c|}{ Pachyseris } \\
\hline Magnetic Island, Australia & 16.0 & $\mathrm{n} / \mathrm{a}$ & 14.0 & nd & 12.0 & 46.0 & nd & 10.0 & Meikle et al. (1988) \\
\hline \multicolumn{10}{|l|}{ Madrepora } \\
\hline Røst Reef, Norway & nd & 31.4 & nd & nd & 42.6 & nd & 26.0 & nd & Present study \\
\hline \multicolumn{10}{|l|}{ Lophelia } \\
\hline Røst Reef, Norway & nd & nd & 8.0 & 1.5 & 18.8 & 4.7 & 9.8 & 57.2 & Present study \\
\hline Tisler Reef, Sweden & nd & nd & nd & nd & 40.4 & nd & 59.6 & nd & \\
\hline $\begin{array}{l}\text { All warm-water corals } \\
(\text { mean } \pm \text { SE) }\end{array}$ & $\begin{array}{r}22.3 \\
\pm 6.4\end{array}$ & $\begin{array}{c}0.8 \\
\pm 0.6\end{array}$ & $\begin{array}{r}22.3 \\
\pm 7.4\end{array}$ & $\begin{array}{c}1.3 \\
\pm 0.7\end{array}$ & $\begin{array}{r}16.1 \\
\pm 2.8\end{array}$ & $\begin{array}{c}5.8 \\
\pm 2.7\end{array}$ & $\begin{array}{r}12.0 \\
\pm 3.5\end{array}$ & $\begin{array}{r}13.1 \\
\pm 3.0\end{array}$ & \\
\hline $\begin{array}{l}\text { All cold-water corals } \\
(\text { mean } \pm \mathrm{SE})\end{array}$ & nd & $\begin{array}{r}10.5 \\
\pm 10.5\end{array}$ & $\begin{array}{c}2.7 \\
\pm 2.7\end{array}$ & $\begin{array}{c}0.5 \\
\pm 0.5\end{array}$ & $\begin{array}{r}33.9 \\
\pm 7.6\end{array}$ & $\begin{array}{c}1.6 \\
\pm 1.6\end{array}$ & $\begin{aligned} & 31.8 \\
\pm & 14.7\end{aligned}$ & $\begin{array}{c}19.1 \\
\pm 19.1\end{array}$ & \\
\hline
\end{tabular}


$(p<0.001)$ more arabinose than all samples $(n=8)$ from 5 other WC genera in the present study. Similarly, mucus derived from different corals of the genus Fungia $(\mathrm{n}=4$ samples in the present study) contained significantly $(p<0.001)$ more fucose than the mucus of all other $7 \mathrm{WC}$ genera in the present study. This indicates a similar carbohydrate composition at the genus level for warm-water corals (Table 1).

The carbohydrate composition difference between the 2 Lophelia mucus samples (Table 1) may be explained by the different $\mathrm{CC}$ reef sampling locations with different environmental conditions, but not by differences in handling, as identical methodologies were used. This is supported by studies on WC indicating that quantity (Naumann et al. in press) and composition (Drollet et al. 1997) of released mucus can change when corals are exposed to different environmental parameters, e.g. light availability, UV radiation, water temperature or inorganic nutrient concentrations.

In the present study, the only carbohydrate component found in the mucus of all coral genera was glucose (Table 1), which represents a universal energy source for most organisms. Glucose contents in mucus from both WC and CC may explain its excellent microbial degradability described by several previous studies (Ducklow 1990, Wild et al. 2004a,b, 2005b). Besides glucose, the neutral monosaccharides arabinose, galactose, xylose and mannose, as well as the amino sugar $\mathrm{N}$-acetyl-glucosamine, have been identified as important substrates supporting bacterial growth and contributing to the flux of labile dissolved organic matter (DOM) in marine waters (Rich et al. 1996, Riemann \& Azam 2002). The concentration of labile monosaccharides in marine waters is usually low (Benner et al. 1992), as hydrolysable neutral sugars are subject to rapid microbial decomposition (Ogawa et al. 2001). Thus the finding that the carbohydrate fraction of coral mucus includes a heterogeneous mixture of labile monosaccharides explains the stimulating influence of both warm- and cold-water coral mucus on planktonic or benthic microbial metabolism (Wild et al. $2005 \mathrm{~b}, 2008)$. The remaining monosaccharide constituents of coral mucus, fucose and rhamnose, likely contribute to the large pool of refractory marine DOM, as previous studies attested a low bacterial degradability of these deoxysugars (Amon et al. 2001, Ogawa et al. 2001).

Arabinose was not detected in any of the azooxanthellate $\mathrm{CC}$, likely because this monosaccharide is usually not a constituent of animal cells, but a characteristic monosaccharide for photosynthetic organisms (Meikle et al. 1988). But rhamnose, fucose, xylose, mannose, galactose, glucose and $\mathrm{N}$-acetyl glucosamine were found in both the mucus of zooxanthellate warm-water and azooxanthellate CC (Table 1), there- fore likely representing principal carbohydrate components of the matrix of scleractinian coral mucus. Comparison of results of the present study with all available similar data sets from the literature (Richards et al. 1983, Meikle et al. 1988, Wild et al. 2005a; see Table 1) revealed no significant differences in glycosyl composition ( $p>0.05$ for single glycosyls except arabinose) between WC $(\mathrm{n}=16$ samples) and CC genera $(\mathrm{n}=$ 3 samples). This indicates use of similar carbohydrate components during mucus synthesis by corals, largely irrespective of different energy supply mechanisms in zooxanthellate or azooxanthellate corals.

The importance of WC derived mucus as a trophic link was suggested in previous studies (Benson \& Muscatine 1974, Ducklow \& Mitchell 1979, Wild et al. 2004b). Cold-water coral-derived mucus, with its high content of the C6 sugars glucose and mannose, which have been shown to primarily fuel microbial production in aquatic ecosystems (Rich et al. 1996), may likely function as a key energy carrier from corals to microbes in CC reef ecosystems.

Acknowledgements. We thank C. Jantzen, S. Schöttner and L. Wehrmann for assistance during sampling. Carbohydrate composition analyses were carried out by the Center of Complex Carbohydrate Research of the University of Georgia in Athens, Georgia, USA. We also would like to acknowledge the responsible editor Dr. P. Sammarco and 2 anonymous reviewers for helping to improve the manuscript. This work was funded by German Research Foundation grant Wi 2677/2-1 to C.W.

\section{LITERATURE CITED}

Allers E, Niesner C, Wild C, Pernthaler J (2008) Microbes enriched in seawater after the addition of coral mucus. Appl Environ Microbiol 74:3274-3278

Amon RMW, Fitznar HP, Benner R (2001) Linkages among the bioreactivity, chemical composition, and diagenetic state of marine dissolved organic matter. Limnol Oceanogr 46: $287-297$

> Arnosti C (2000) Substrate specificity in polysaccharide hydrolysis: contrasts between bottom water and sediments. Limnol Oceanogr 45:1112-1119

Benner R, Pakulski JD, McCarthy M, Hedges JI, Hatcher PG (1992) Bulk chemical characteristics of dissolved organic matter in the ocean. Science 255:1561-1564

Benson A, Muscatine L (1974) Wax in coral mucus: energy transfer from corals to reef fishes. Limnol Oceanogr 19: 810-814

> Brown BE, Bythell JC (2005) Perspectives on mucus secretion in reef corals. Mar Ecol Prog Ser 296:291-309

Coffroth MA (1990) Mucous sheet formation on poritid corals: an evaluation of coral mucus as a nutrient source on reefs. Mar Biol 105:39-49

Crossland C, Barnes D, Borowitzka M (1980) Diurnal lipid and mucus production in the staghorn coral Acropora acuminata. Mar Biol 60:81-90

Davies PS (1984) The role of zooxanthellae in the nutritional energy requirements of Pocillopora eydouxi. Coral Reefs 2:181-186 
Drollet JH, Teai T, Faucon M, Martin PMV (1997) Field study of compensatory changes in UV-absorbing compounds in the mucus of the solitary coral Fungia repanda (Scleractinia: Fungiidae) in relation to solar UV radiation, seawater temperature, and other coincident physico-chemical parameters. Mar Freshw Res 48:329-333

Ducklow HW (1990) The biomass, production and fate of bacteria in coral reefs. In: Dubinsky Z (ed) Coral reefs. Ecosystems of the world, Vol 25. Elsevier, Amsterdam, p 265-289

Ducklow HW, Mitchell R (1979) Composition of mucus released by coral reef coelenterates. Limnol Oceanogr 24:706-714

Huettel M, Wild C, Gonelli S (2006) The mucus trap in coral reefs: formation and temporal evolution of particle aggregates caused by coral mucus. Mar Ecol Prog Ser 307:69-84

Johannes RE (1967) Ecology of organic aggregates in the vicinity of a coral reef. Limnol Oceanogr 12:189-195

Marshall M (1968) Observations on organic aggregates in the vicinity of coral reefs. Mar Biol 2:50-55

Meikle P, Richards G, Yellowlees D (1988) Structural investigations on the mucus from 6 species of coral. Mar Biol 99: 187-193

Merkle RK, Poppe I (1994) Carbohydrate composition analysis of glycoconjugates by gas-liquid chromatography/ mass spectrometry. Methods Enzymol 230:1-15

Naumann MS, Richter C, el-Zibdah M, Wild C (2009) Coral mucus as an efficient trap for picoplanktonic cyanobacteria: implications for pelagic-benthic coupling in the reef ecosystem. Mar Ecol Prog Ser 385:65-76

Naumann MS, Haar AF, Struck U, Mayr C, el-Zibdah M, Wild $\mathrm{C}$ (in press) Organic matter release by the dominant hermatypic corals of the northern Red Sea. Coral Reefs

Ogawa H, Amagai Y, Koike I, Kaiser K, Benner R (2001) Production of refractory dissolved organic matter by bacteria. Science 292:917-920

Rich JH, Ducklow HW, Kirchman DL (1996) Concentrations and uptake of neutral monosaccharides along $140^{\circ} \mathrm{W}$ in the equatorial Pacific: contribution of glucose to heterotrophic bacterial activity and the DOM flux. Limnol

Editorial responsibility: Paul Sammarco,

Chauvin, Louisiana, USA
Oceanogr 41:595-604

Richards GN, Meikle PJ, Yellowlees D (1983) Preliminary investigations into the chemical nature of mucus from the staghorn coral (Acropora formosa). Proc Inaug Great Barrier Reef Conf 1:353-359

> Riemann L, Azam F (2002) Widespread N-acetyl-D-glucosamine uptake among pelagic marine bacteria and its ecological implications. Appl Environ Microbiol 68: $5554-5562$

Schöttner S, Hoffmann F, Wild C, Rapp HT, Boetius A, Ramette A (2009) Inter- and intra-habitat bacterial diversity associated with cold-water corals. ISME J 3:756-759

Wild C, Huettel M, Klueter A, Kremb SG, Rasheed M, Jørgensen BB (2004a) Coral mucus functions as an energy carrier and particle trap in the reef ecosystem. Nature 428: $66-70$

Wild C, Rasheed M, Werner U, Franke U, Johnstone R, Huettel M (2004b) Degradation and mineralization of coral mucus in reef environments. Mar Ecol Prog Ser 267:159-171

Wild C, Woyt H, Huettel M (2005a) Influence of coral mucus release on nutrient fluxes in carbonate sands. Mar Ecol Prog Ser 287:87-98

Wild C, Rasheed M, Jantzen C, Cook P, Struck U, Huettel M, Boetius A (2005b) Benthic metabolism and degradation of natural particulate organic matter in carbonate and silicate sands of the northern Red Sea. Mar Ecol Prog Ser 298: 69-78

Wild C, Mayr C, Wehrmann L, Schöttner S, Naumann M, Hoffmann F, Rapp HT (2008) Organic matter release by cold water corals and its implication for fauna-microbe interaction. Mar Ecol Prog Ser 372:67-75

> Wild C, Wehrmann LM, Mayr C, Schöttner SI, Allers E, Lundälv T (2009) Microbial degradation of cold-water coral-derived organic matter: potential implication for organic C cycling in the water column above Tisler Reef. Aquat Biol 7:71-80

York WS, Darvill AG, McNeil M, Stevenson TT, Albersheim P (1986) Isolation and characterization of plant cell walls and cell wall components. Methods Enzymol 118:3-40

Submitted: October 13, 2009; Accepted: June 9, 2010

Proofs received from author(s): June 30, 2010 